\title{
Suppressed Expression but Not Activity of Collagenases MMP-1 and MMP-13 in Human Renal Carcinoma
}

\author{
Grzegorz Młynarczyk $^{\mathrm{a}, \mathrm{b}} \quad$ Jacek Kudelski $^{\mathrm{b}}$ Barbara Darewicz ${ }^{\mathrm{b}}$ \\ Marta Bruczko-Goralewska ${ }^{\text {a }}$ Lech Romanowicz ${ }^{a}$

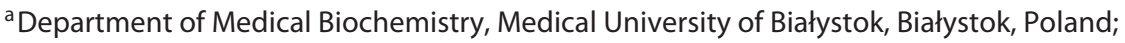 \\ ${ }^{\mathrm{b}}$ Department of Urology, Medical University of Białystok, Białystok, Poland
}

\section{Keywords}

Renal carcinoma $\cdot$ Collagen $\cdot$ Collagenases $\cdot$ MMP-1/13

\begin{abstract}
Background: Collagenases are enzymes starting collagen degradation. The role of collagenases in renal carcinoma development is not well understood. Objective: Evaluation of collagen content and collagenase expression and activity in human kidney cancers. Methods: Collagen content was measured by the hydroxyproline assay. The expression and the content of collagenases were evaluated by Western blotting and ELISA. Fluorogenic substrate was used to measure enzyme activity. Results: Collagen content significantly decreases with the progression of kidney cancer. Both collagenases are first present in high molecular complexes in both control and cancer tissue. The healthy part of the kidney contains similar amounts of both collagenases. Collagenase content decreased significantly in tumor tissue with increasing cancer stage. MMP-13 activity is much higher than that of MMP-1 in all tissues investigated. We observed increasing collagenase activity (MMP-1 and MMP-13) with increasing renal cancer grade. Conclusions: The lower content and higher activity of the collagenases investigated in cancer tis-
\end{abstract}

() 2019 S. Karger AG, Basel

E-Mail karger@karger.com

www.karger.com/pat sue indicate that most of these enzymes are in active form in renal carcinoma. The lower collagen content in cancer tissue can be explained at least in part by increased collagenase activity.

(c) 2019 S. Karger AG, Basel

\section{Introduction}

An appropriate structure of the extracellular matrix (ECM) determines the proper functioning of kidneys. Collagen is the main extracellular protein, and the collagen content depends on the balance between its synthesis and degradation [1-3]. Collagen is mainly degraded by matrix metalloproteinases (MMPs), especially by collagenases that are the only enzymes able to cleave the triplehelical structure of native collagen [4-6]. Moreover, collagenases perform other functions that may regulate ECM metabolism. Collagenase 1 (MMP-1) also degrades other extracellular components, e.g., proteoglycans or structural proteins $[7,8]$, enabling thus cell migration or the release of biologically active molecules from ECM stores. On the other hand, MMP-1 is engaged in changes of molecular biological activity by cleavage. Degradation 
of insulin-like growth factor binding proteins makes the growth factor action on neighboring cells possible. Cleavage of tumor necrosis factor- $\alpha$ by MMP-1 inactivates it [9]. Besides collagen degradation, collagenase 3 (MMP13) may function by activating or degrading key regulatory proteins, such as transforming growth factor- $\beta 1$ [10]. It may also play a role in cell migration and tumor cell invasion [11]. Moreover, MMP-13 plays a central role in the MMP activation cascade via both activating and being activated by several MMPs [12]. The activity of both collagenases is regulated by limited cleavage and by binding of 1 of 3 MMP tissue inhibitors: TIMP1-TIMP3 $[13,14]$.

The role of collagenases in renal carcinoma development is not well understood. We decided to evaluate the expression, content, and activity of collagenase 1 (MMP-1) and collagenase 3 (MMP-13) in cancerous tissue in comparison with healthy control tissue of the human kidney.

\section{Materials and Methods}

\section{Tissue Material}

The study group comprised patients with clear-cell kidney cancer at G2 and G3 stage of the International Society of Urological Pathology/WHO malignancy scale. All patients underwent radical surgical treatment, which was open nephrectomy. Twenty patients (6 females and 14 males) were qualified for this study. Patient age ranged from 48 to 78 years. The study material included excised primary tumor tissue collected during the surgical procedure. $\mathrm{Pa}$ tients with G2 $(n=10)$ and G3 $(n=10)$ cancer were selected. After tumor excision, all patients with G2 kidney cancer were alive at the last follow-up. Two of the 10 patients with G3 cancer succumbed. Diagnosis delay, i.e., the time from first symptom occurrence to proper diagnosis, was $5.75 \pm 1.78$ months for patients with G2 cancer and $4.50 \pm 1.98$ months for patients with G3 cancer. Disease duration, i.e., the time from diagnosis to surgery, was $7.6 \pm 2.3$ weeks for patients with G2 cancer and $7.4 \pm 1.8$ weeks for patients with G3 cancer.

Tissue extracts of the same kidney but from the opposite localization to the tumor were considered as a control. Any carcinogenetic lesion was not macroscopically visible in control tissue. All samples collected were washed with a $0.9 \% \mathrm{NaCl}$ solution, portioned, and stored at $-70^{\circ} \mathrm{C}$ until the whole analysis. Surgical procedures were performed in the Department of Urology at the University Hospital in Białystok.

\section{Extract Preparation}

Tissue homogenates $(20 \%, \mathrm{w} / \mathrm{v})$ were prepared in $0.05 \mathrm{M}$ Tris/ $\mathrm{HCl}$ buffer, $\mathrm{pH} 7.4$, with the use of a knife homogenizer $(20,000$ $\left.\mathrm{rpm}, 3 \times 30 \mathrm{~s}, 0^{\circ} \mathrm{C}\right)$. The homogenates were subjected to ultrasonic treatment $\left(20 \mathrm{kHz}, 3 \times 15 \mathrm{~s}, 0^{\circ} \mathrm{C}\right)$ followed by centrifugation at $10,000 \mathrm{~g}$ for $30 \mathrm{~min}$ at $4^{\circ} \mathrm{C}$. The supernatants (tissue extracts) were collected and stored at $-70^{\circ} \mathrm{C}$ for further use.
Collagen content was measured by the assay of hydroxyproline as described previously [15]. Since hydroxyproline constitutes about $1 / 8(\mathrm{w} / \mathrm{w})$ of collagen weight, the approximate amount of that protein in renal tissue has been calculated by multiplication of the hydroxyproline content by 8 .

\section{Collagenase Content}

The content of collagenases was determined with commercially available ELISA kits according to the manufacturers' instruction (MMP-1 - Sigma, cat. No. RAB0362; MMP-13 - Cloud-Clone Corp. cat. No. SEA0999Hu).

\section{Western Blot Analyses of Collagenases}

The samples of tissue extracts were electrophoresed on $10 \%$ SDS-polyacrylamide gel according to the method of Laemmli [16] in nonreducing and reducing conditions. Western blot was performed according to a previously described procedure [17]. The following primary antibodies were used to detect MMPs: mouse monoclonal antibody for human MMP-1 (cat. No. MAB901; R\&D Systems; 1:200) and rabbit polyclonal antibody for human MMP13 (cat. No. sc-30073; Santa Cruz Biotechnology; 1:1,000). Bound antibodies were detected using alkaline phosphatase conjugated with goat anti-mouse (cat. No. A2429; Sigma) or goat anti-rabbit secondary antibody (cat. No. A9919; Sigma) and next BCIP/NBT reagent (cat. No. B1911; Sigma).

\section{Collagenase Activity}

Actual specific activity of MMP-1 and MMP-13 was measured in black 96-well flat-bottom microplates precoated with the respective specific MMP antibody (the same antibodies that were used in Western blot analysis) [18]. The appropriate sample was added to each well for MMP immobilization. Microplates were incubated overnight at $4{ }^{\circ} \mathrm{C}$. All other proteins were washed out with TBS-T buffer ( $50 \mathrm{~mm}$ Tris/ $\mathrm{HCl}, \mathrm{pH} 7.4,0.9 \% \mathrm{NaCl}, 0.05 \%$ Tween 20). MMP activity was measured in buffer (50 mM Tris/ $\mathrm{HCl}, \mathrm{pH}$ 7.5) containing $10 \mathrm{mM} \mathrm{CaCl}_{2}, 150 \mathrm{mM} \mathrm{NaCl}$, and $0.025 \%$ Brij 35 [19] with MCA-Pro-Leu-Ala-Cys (p-OMeBz)-Trp-AlaArg (Dpa)-H2 (Merck, cat. No. 444258) as a fluorogenic substrate ( $4 \mu \mathrm{M}$ final concentration). Microplates were incubated at $37^{\circ} \mathrm{C}$ for 60 min with gentle shaking. The reaction was stopped by addition of $100 \mathrm{~mm}$ EDTA $\mathrm{Na}_{2}$. Degradation of the fluorogenic substrate was measured with a spectrophoto-fluorimetric/multimode microplate reader (Tecan Infinite ${ }^{\circledR} 200$ PRO; Tecan) with excitation and emission wavelengths set at 325 and $393 \mathrm{~nm}$, respectively. The quantity of degraded substrate was calculated from the calibration curve prepared at the same condition with 7-amino-4-methylcoumarin (Sigma-Aldrich; cat. No. 257370) as a standard. MMP-specific activity was expressed in katals per kilogram of protein.

\section{Protein Determination}

Protein concentration was measured according to the Bradford method [20].

\section{Statistical Analysis}

Mean values from 10 assays \pm standard deviations (SD) were calculated. The results were submitted to statistical analysis with the use of Student's $t$ test, accepting $p<0.05$ as significant. 


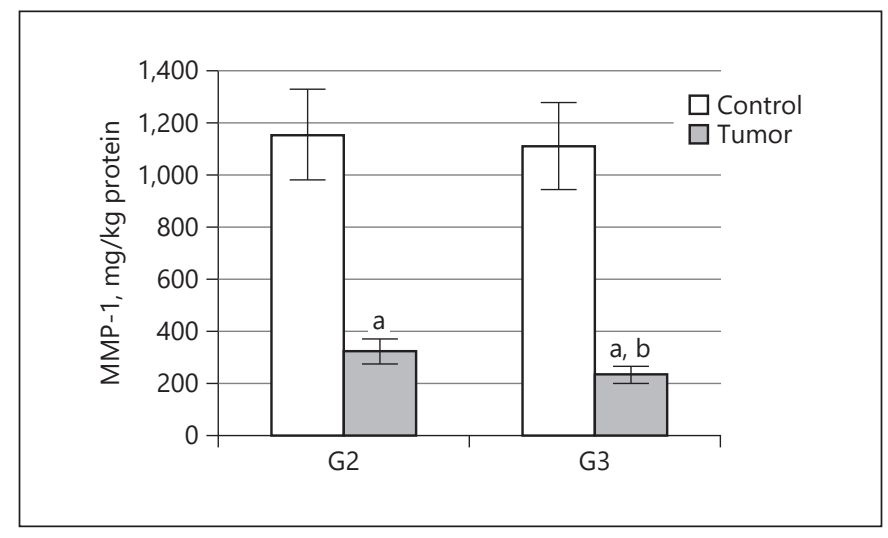

Fig. 1. Content of MMP-1 in control tissue and grade (G) 2 and G3 human kidney tumor. ${ }^{a} p<0.001$ vs. respective control kidney, ${ }^{\mathrm{b}} p<0.001$ vs. G2 human kidney cancer.

\section{Results}

Collagen contents are presented in Table 1. It was found that normal human kidney contained about $70 \mathrm{mg}$ of collagen per gram of dry tissue. G2 human kidney tumor tissue was characterized by $65 \%$ of control quantity, while in G3 kidney cancer the collagen content was more than halved in comparison to the respective control tissue (Table 1).

MMP-1 and MMP-13 contents are shown in Figures 1 and 2 , respectively. Collagenase 1 was present in extremely high amount in normal tissue extracts, about $1.1 \mathrm{~g} / \mathrm{kg}$ of protein. G2 and G3 tumor extracts contained significantly lower amounts of MMP-1 compared to control, almost 72\% less in grade (G) 2 and 79\% less in G3 (Fig. 1). The content of MMP-13 (Fig. 2) in the normal kidney was similar as MMP-1, about $1 \mathrm{~g} / \mathrm{kg}$ of total protein content. It was observed that in G2 the MMP-13 content decreased $84 \%$ in comparison to the respective control tissue, and in G3 about $90 \%$. Similarly to MMP-1, MMP-13 content significantly decreased with the development of tumor invasiveness (Fig. 2).

Collagenase expression was analyzed by Western blot and representative blots for MMP-1 (Fig. 3) and MMP-13 (Fig. 4). All tissues investigated contained MMP-1 in high molecular complexes presenting as a band with a molecular weight of about $240 \mathrm{kDa}$ in nonreducing conditions (lane 1-4; Fig. 3). Additionally, 2 bands with molecular masses of about 130 and $85 \mathrm{kDa}$ (lanes 1 and 3) were detected in the control tissues. Moreover, in the control tissues and G3, a tumor band with a molecular weight of 45 $\mathrm{kDa}$ (lanes 1, 3, and 4; Fig. 3) was detected. Disulfide bridge reduction with $\beta$-mercaptoethanol resulted in dis-

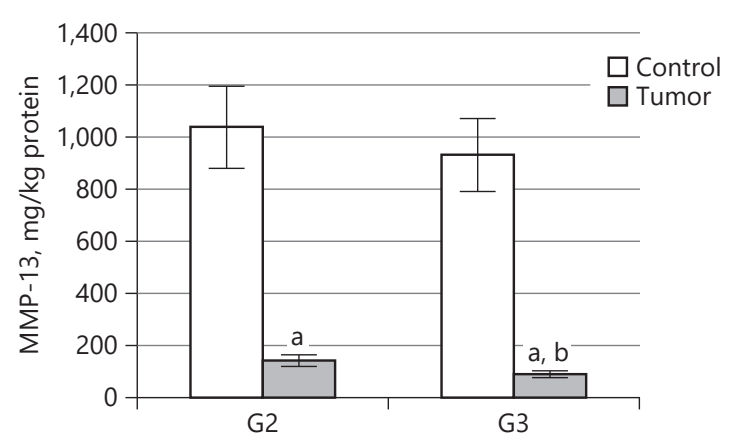

Fig. 2. Content of MMP-13 in control tissue and grade (G) 2 and G3 human kidney tumor. ${ }^{\mathrm{a}} p<0.001$ vs. respective control kidney, ${ }^{\mathrm{b}} p<0.001$ vs. G2 grade human kidney cancer.

Table 1. Total content of hydroxyproline and collagen in respective control kidney and in G2 and G3 tumor

\begin{tabular}{lll}
\hline Kidney & $\begin{array}{l}\text { Hydroxyproline, } \\
\text { mg/g dry tissue }\end{array}$ & $\begin{array}{l}\text { Collagen, } \\
\text { mg/g dry tissue }\end{array}$ \\
\hline Control to G2 & $8.47 \pm 1.31$ & $67.7 \pm 11.1$ \\
Tumor G2 & $5.48 \pm 0.90^{\mathrm{a}}$ & $43.8 \pm 7.8^{\mathrm{a}}$ \\
Control to G3 & $8.67 \pm 1.43$ & $69.3 \pm 11.9$ \\
Tumor G3 & $3.47 \pm 0.78^{\mathrm{a}, \mathrm{b}}$ & $27.8 \pm 7.0^{\mathrm{a}, \mathrm{b}}$ \\
\hline
\end{tabular}

${ }^{\mathrm{a}} p<0.001$ vs. control, ${ }^{\mathrm{b}} p<0.001$ vs. G2 tumor.

appearance of high-molecular-weight complexes of MMP-1 in all investigated tissue extracts (lanes 5-8; Fig. 3). Both control tissues showed a weak band with a molecular weight of about $55 \mathrm{kDa}$ (lanes 5 and 7). Tumor and control tissue extracts presented a weak band with a molecular weight of $45 \mathrm{kDa}$ (lanes 5-8) and a clearly visible band that corresponds to a mass of $25 \mathrm{kDa}$ (Fig. 3). In the case of MMP-13, even with a protein load on the gel as low as $2 \mu \mathrm{g}$, wide bands at 115 and about $48 \mathrm{kDa}$ were obtained in all tissues investigated (lanes 1-4; Fig. 4) in nonreducing conditions. Dark lanes above the band of $115 \mathrm{kDa}$ suggest the presence of MMP-13 in high mass complexes in normal and tumor tissue. Control kidneys and tumor tissue of G2 showed an additional band with a molecular weight of about $80 \mathrm{kDa}$ (lanes 1-3; Fig. 4). Those subjects also gave a narrow band with an extremely low molecular weight of $17 \mathrm{kDa}$ (lanes 1-4; Fig. 4). In reducing conditions, only 2 bands with a molecular weight of about 60 and $48 \mathrm{kDa}$ appeared in all investi- 


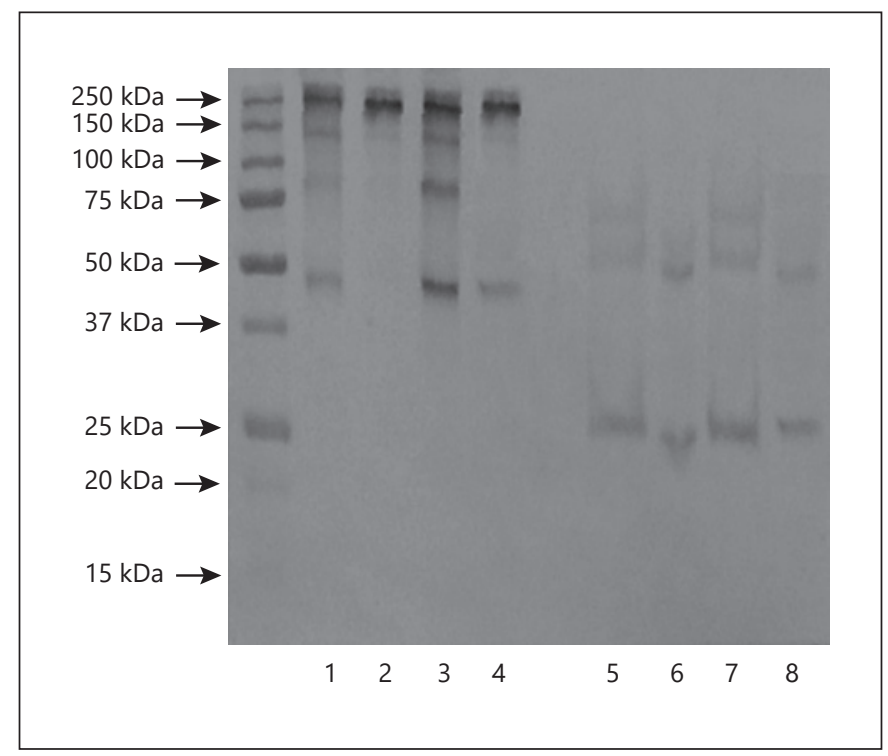

Fig. 3. Western immunoblot of MMP-1 in respective control tissue and grade $(\mathrm{G}) 2$ and $\mathrm{G} 3$ human kidney tumor; $10 \mu \mathrm{g}$ of protein were applied on the gel. Separation in nonreducing conditions: lanes: 1, control kidney for G2 tumor; 2, G2 kidney tumor; 3, control kidney for G3 tumor; 4, G3 kidney tumor; separation in reducing conditions: lanes: 5, control kidney for G2 tumor; 6, G2 of kidney tumor; 7, control kidney for G3 tumor; 8, G3 of kidney tumor.

gated tissues (lanes 5-8; Fig. 4). An additional band corresponding to $17 \mathrm{kDa}$ was visible for both control tissues and tumor tissue of G2 (lane 5-7; Fig. 4), similarly to samples without reducing agent.

Figure 5 a presents the actual activity of MMP-1 calculated per $\mathrm{kg}$ of total protein. Comparable activity of MMP-1 has been demonstrated for the control tissue and G3 cancer. In contrast, MMP-1 showed significantly reduced activity in relation to the control tissue and accounted for only $6 \%$ of its activity in the respective control tissue. MMP-1 actual activity in G3 tumor was more than 18 times higher when compared to G2 tumor, and the differences were statistically significant (Fig. 5a).

Additionally, in Figure 5b, the actual specific activity of collagenase 1 was expressed per kilogram of the enzyme protein. Both control tissues were characterized by similar actual specific activity, about $70 \mu \mathrm{katal} / \mathrm{kg}$ of MMP-1. The G2 tumor tissue presented almost 4 times lower activity when compared to the respective control, and the differences were significant. However, the G3 tumor tissue showed extremely high actual specific activity of MMP-1, which was more than 5 times higher in comparison to the respective control material (Fig. 5b).

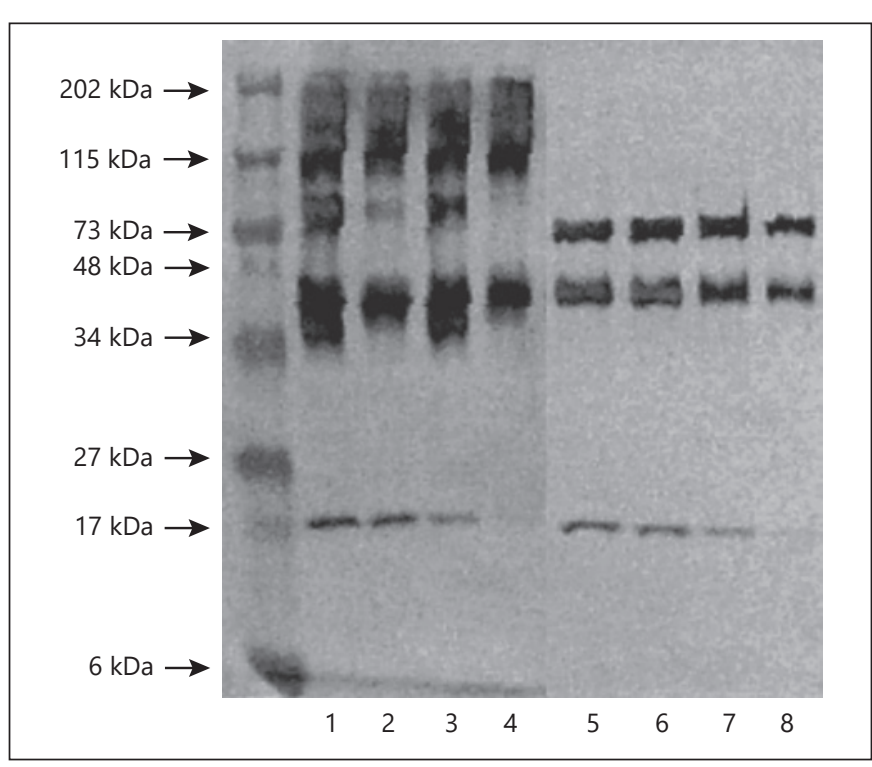

Fig. 4. Western immunoblot of MMP-13 in respective control tissue and grade $(G) 2$ and G3 human kidney tumor; $2 \mu \mathrm{g}$ of protein were applied on the gel. Separation in nonreducing conditions: lanes: 1, control kidney for G2 tumor; 2, G2 of kidney tumor; 3, control kidney for G3 tumor; 4, G3 of kidney tumor; separation in reducing conditions: lanes: 5, control kidney for G2 tumor; 6, G2 of kidney tumor; 7, control kidney for G3 tumor; 8, G3 of kidney tumor.

Figure 6a presents the actual activity of MMP-13 calculated per kilogram of total protein. MMP-13 activity was significantly reduced in both grades of cancer when compared to respective control tissue. The activity of the enzyme significantly increased with the degree of tumor development but did not reach the control value (Fig. 6a).

The actual specific activity of MMP-13 expressed per kilogram of the enzyme protein (Fig. 6b) was significantly increased in both grades of cancer in relation to the respective control tissue. In G2 tumor tissue, there was more than two times higher activity in comparison to the control tissue, while the activity of MMP-13 in G3 tumor tissue was about $550 \%$ higher than in the respective control tissue and more than twice higher when compared to the G2 tumor tissue (Fig. 6b).

\section{Discussion}

Collagen is the main ECM protein [21, 22]. In this study, we found a significantly decreased total collagen content in the cancer tissue compared to the respective control tissue, which decreased with increasing tumor 


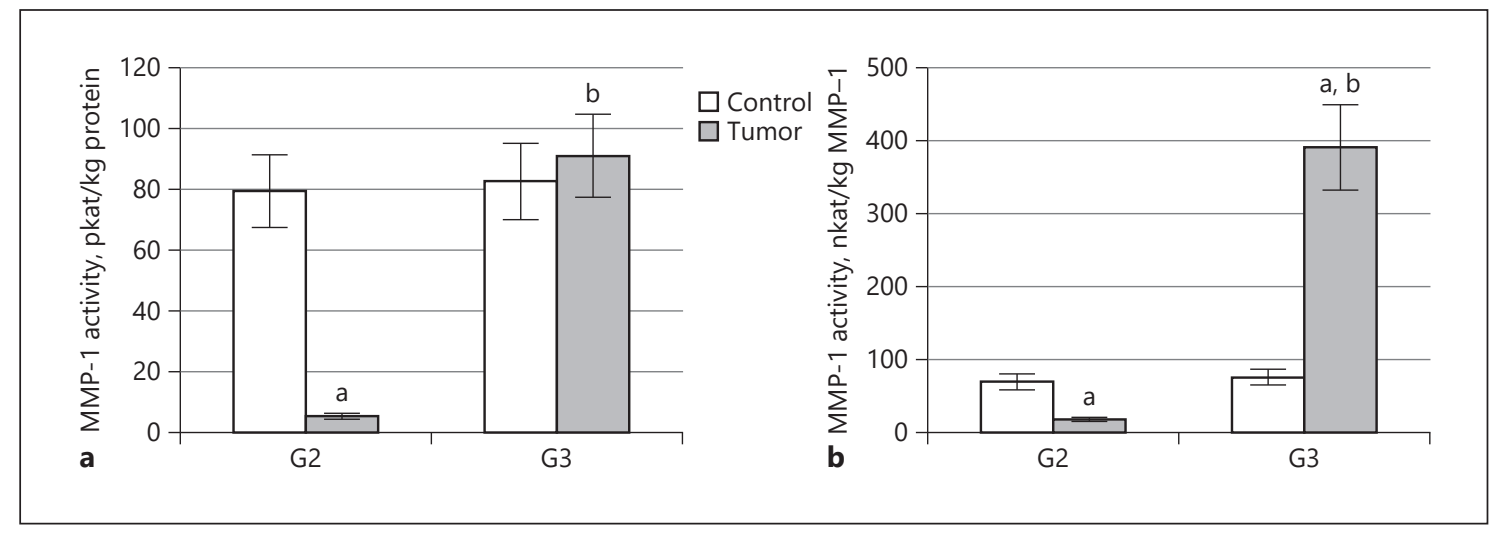

Fig. 5. a MMP-1 actual activity expressed in katals per kilogram of total protein in respective control tissue and grade (G) 2 and G3 human kidney tumor. b MMP-1 actual specific activity expressed in katals per kilogram of the enzyme protein in the same tissues. ${ }^{\mathrm{a}} p<0.001$ vs. respective control kidney, ${ }^{\mathrm{b}} p<0.001 \mathrm{vs.} \mathrm{G2} \mathrm{human} \mathrm{kidney}$ cancer.

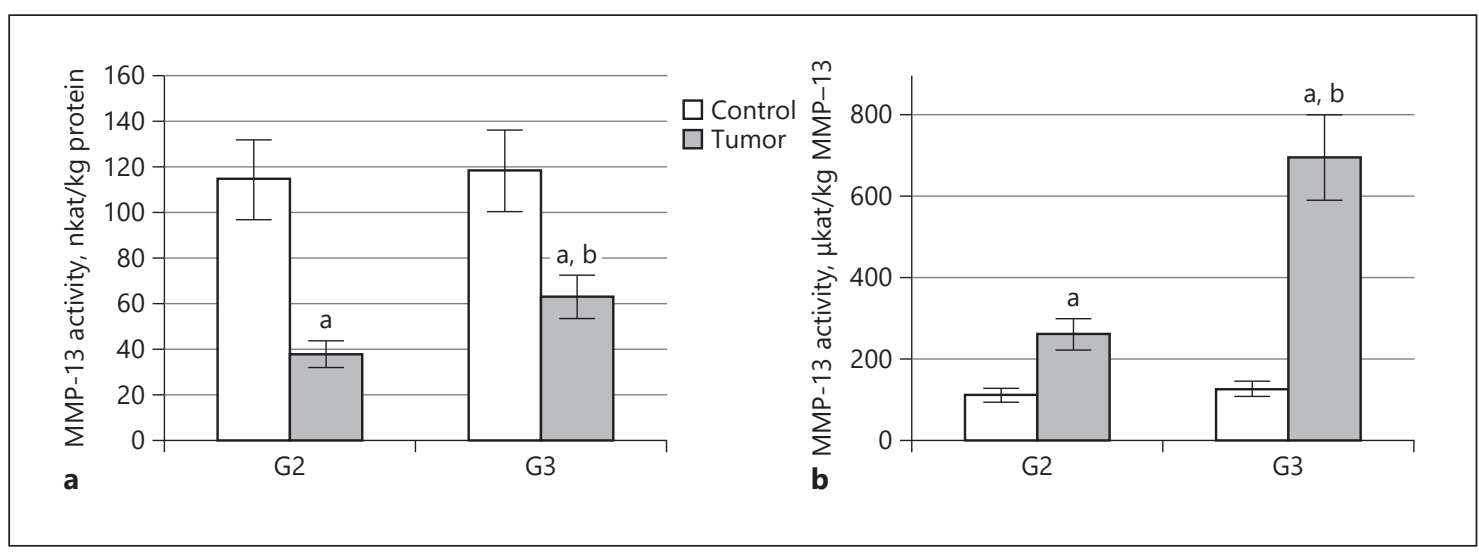

Fig. 6. a MMP-13 actual activity expressed in katals per kilogram of total protein in respective control tissue and grade (G) 2 and G3 human kidney tumor. b MMP-13 actual specific activity expressed in katals per kilogram of the enzyme protein in the same tissues. ${ }^{\mathrm{a}} p<0.001$ vs. respective control kidney, ${ }^{\mathrm{b}} p<0.001$ vs. G2 human kidney cancer.

grade. It can result from either decreased collagen synthesis or enhancement of its degradation, or both phenomena simultaneously [23-25]. We decided to evaluate the content and activity of enzymes engaged in collagen degradation in kidney cancer development.

Collagenases are the enzymes which begin collagen degradation in the extracellular space. Our results indicate that cancer development and enhancement of tumor invasiveness from G2 to G3 are accompanied by a significant decrease in the content of both collagenases, which seems to be in opposition to the results of other investigators. Bhuvarahamurthy et al. [26] have found no differences in collagenase 1 expression between normal and malignant renal cells at mRNA level, while they observed high enzyme protein amounts in cancer cells even with different expression patterns for different cellular compartments [26].

Taking their and our results together, it can be concluded that malignant and normal renal cells differ in MMP-1 secretion outside the cell. Collagenase 1 synthesis is at a similar level in both kind of cells, but cancer cells limit the secretion of the enzyme to the extracellular space. It is well known that protein turnover inside the cell is much faster than outside [27]. Since MMP-1 is an 
extracellular enzyme, the low MMP-1 content in cancer tissue may be explained by limited enzyme secretion by malignant cells.

Similarly to collagenase 1 , low levels of collagenase 3 mRNA expression in primary renal carcinoma cells and adjacent normal kidney have been found by Kominsky et al. [10]. They have also observed a low MMP-13 protein content in cancer tissue [10], which is in agreement with our results.

Western blot analysis indicates that both investigated collagenases are present first of all in high molecular complexes in control kidney and in cancers of both grades. Those complexes disappear after reduction in disulfide bridges, which means that bonds joining all the components together are rather weak and noncovalent. Free forms of MMP-1 with a molecular mass of $45 \mathrm{kDa}[11,13]$ and MMP-3 with a molecular mass of $48 \mathrm{kDa}[3,5,7]$ were present in all control and cancer tissues in reducing conditions. An active form of MMP-13 was also visible in nonreducing conditions. The proenzymatic form of MMP-1 with a molecular mass of $55 \mathrm{kDa}[7,11,13]$ was not detected in any cancer tissue sample even after a reduction in disulfide bonds. Interestingly, the reduction in disulfide bridges evokes the disappearance of most bands which reacted with MMP-1 antibody that were observed in nonreducing conditions. It can be supposed that collagenase 1 molecules are partially cleaved into shorter chains grouped by zinc and calcium ions and 1 disulfide bridge in the hemopexin domain $[11,13]$. Unlike MMP-1, the free latent form of MMP-13 with a molecular mass of $60 \mathrm{kDa}$ [28] appeared by the action of a reducing agent. Additionally, a clearly visible narrow band with a molecular weight of $17 \mathrm{kDa}$, present in both control tissue and G2 tumor, may represent an MMP-13 degradation product long enough to bind specific antibody.

Our results show that the actual activity of MMP-13 in the human kidney, presented per kilogram of total protein content, is about a thousand times higher than that of MMP-1 in both healthy and cancer tissue. Both collagenases have few times lower activity in renal carcinoma compared to control, especially in the G2 stadium. Significant increases in the activity of both enzymes are observed with increasing cancer stage, which may partially explain the decreased total collagen content in the cancer tissue at more advanced stages.

Collagenase-specific activity calculated per kilogram of the enzyme protein amount suggests what part of the enzyme is in the active form without any inhibitor bound to the active site of the enzyme. MMP-13 shows much higher specific activity in control tissue than MMP-1. Sig- nificantly higher specific activity of MMP-13 has been detected in cancer tissue in comparison to control tissue with its increase in G3 stadium versus G2 stadium. An extremely huge increase in specific activity of collagenase 1 in G3 kidney cancer has been found. It seems that most of MMP-1 and MMP-13 - especially in advanced stages of kidney cancer - is in active form without inhibitory effects of TIMPs.

In summary, our results present different changes in the amount and activity of the investigated collagenases in healthy and cancerous human kidney. A decreased collagen content is accompanied by decreased amounts of MMP-1 and MMP-13. However, the specific activity of both collagenases significantly increases with increasing tumor grade in renal cancer. It indicates differences in the regulation of MMP expression and activation in human kidney cancer.

\section{Statement of Ethics}

The study protocol was approved by the Bioethical Committee of the Medical University of Bialystok, and subjects have given their written informed consent.

\section{Disclosure Statement}

The authors have no conflicts of interest to declare.

\section{Funding Sources}

This research was carried out in relation with statutory activities of research units financed by the Polish Ministry of Science and Higher Education (N/ST/MN/16/001/1115).

\section{Author Contributions}

Grzegorz Młynarczyk - conception and study design, collection of data, writing the paper; Jacek Kudelski - data analysis; Barbara Darewicz and Marta Bruczko-Goralewska - review of the article; and Lech Romanowicz - conception, study design, approval of the final version of the article.

References

1 Frantz C, Stewart KM, Weaver VM. The extracellular matrix at a glance. J Cell Sci. 2010 Dec;123(Pt 24):4195-200.

2 Aumailley M, Gayraud B. Structure and biological activity of the extracellular matrix. J Mol Med (Berl). 1998 Mar;76(3-4):25365. 
3 Bonnans C, Chou J, Werb Z. Remodelling the extracellular matrix in development and disease. Nat Rev Mol Cell Biol. 2014 Dec;15(12): 786-801.

4 Jabłońska-Trypuć A, Matejczyk M, Rosochacki S. Matrix metalloproteinases (MMPs), the main extracellular matrix (ECM) enzymes in collagen degradation, as a target for anticancer drugs. J Enzyme Inhib Med Chem. 2016;31(sup1):177-183.

5 Ala-aho R, Kähäri VM. Collagenases in cancer. Biochimie. 2005 Mar-Apr;87(3-4):27386.

6 Bode W, Maskos K. Structural basis of the matrix metalloproteinases and their physiological inhibitors, the tissue inhibitors of metalloproteinases. Biol Chem. 2003 Jun;384(6): 863-72.

7 Zitka O, Kukacka J, Krizkova S, Huska D, Adam V, Masarik M, et al. Matrix metalloproteinases. Curr Med Chem. 2010;17(31):375168.

8 Fink K, Boratyński J. Rola metaloproteinaz w modyfikacji macierzy zewnątrzkomórkowej $\mathrm{w}$ nowotworowym wzroście inwazyjnym, w przerzutowaniu $\mathrm{i} \mathrm{w}$ angiogenezie. Postepy Hig Med Dosw. 2012;66:609-28.

9 Pardo A, Selman M. MMP-1: the elder of the family. Int J Biochem Cell Biol. 2005 Feb; 37(2):283-8.

10 Kominsky SL, Doucet M, Thorpe M, Weber KL. MMP-13 is over-expressed in renal cell carcinoma bone metastasis and is induced by TGF-beta1. Clin Exp Metastasis. 2008;25(8): $865-70$.

11 Raffetto JD, Khalil RA. Matrix metalloproteinases and their inhibitors in vascular remodeling and vascular disease. Biochem Pharmacol. 2008 Jan;75(2):346-59.
12 Leeman MF, Curran S, Murray GI. The structure, regulation, and function of human matrix metalloproteinase-13. Crit Rev Biochem Mol Biol. 2002;37(3):149-66.

13 Maskos K, Bode W. Structural basis of matrix metalloproteinases and tissue inhibitors of metalloproteinases. Mol Biotechnol. 2003 Nov;25(3):241-66.

14 Brew K, Dinakarpandian D, Nagase H. Tissue inhibitors of metalloproteinases: evolution, structure and function. Biochim Biophys Acta. 2000 Mar; 1477(1-2):267-83.

15 Romanowicz L, Sobolewski K. Extracellular matrix components of the wall of umbilical cord vein and their alterations in pre-eclampsia. J Perinat Med. 2000;28(2):140-6.

16 Laemmli UK. Cleavage of structural proteins during the assembly of the head of bacteriophage T4. Nature. 1970 Aug;227(5259): 680-5.

17 Galewska Z, Romanowicz L, Gogiel T, Jaworski S, Bańkowski E. The inhibitory effect of preeclamptic umbilical cord blood serum on matrix metalloproteinase- 1 in arterial slices incubated in vitro. Pathobiology. 2006;73(6): 310-6.

18 Shi ZD, Ji XY, Qazi H, Tarbell JM. Interstitial flow promotes vascular fibroblast, myofibroblast, and smooth muscle cell motility in 3-D collagen I via upregulation of MMP-1. Am J Physiol Heart Circ Physiol. 2009 Oct;297 (4):H1225-34.

19 Watkins GA, Jones EF, Scott Shell M, VanBrocklin HF, Pan MH, Hanrahan SM, et al. Development of an optimized activatable MMP-14 targeted SPECT imaging probe. Bioorg Med Chem. 2009 Jan;17(2):653-9.
20 Bradford MM. A rapid and sensitive method for the quantitation of microgram quantities of protein utilizing the principle of proteindye binding. Anal Biochem. 1976 May;72(12):248-54.

21 Genovese F, Manresa AA, Leeming DJ, Karsdal MA, Boor P. The extracellular matrix in the kidney: a source of novel non-invasive biomarkers of kidney fibrosis? Fibrogenesis Tissue Repair. 2014 Mar;7(1):4.

22 Crowe DL, Shuler CF. Regulation of tumor cell invasion by extracellular matrix. Histol Histopathol. 1999 Apr;14(2):665-71.

23 Cannon GM Jr, Getzenberg RH. Urinary matrix metalloproteinase activity is not significantly altered in patients with renal cell carcinoma. Urology. 2006 Apr;67(4):848-50.

24 Catania JM, Chen G, Parrish AR. Role of matrix metalloproteinases in renal pathophysiologies. Am J Physiol Renal Physiol. 2007 Mar;292(3):F905-11.

25 Chen YM, Miner JH. Glomerular basement membrane and related glomerular disease. Transl Res. 2012 Oct;160(4):291-7.

26 Bhuvarahamurthy V, Kristiansen GO, Johannsen M, Loening SA, Schnorr D, Jung K, et al. In situ gene expression and localization of MMP1, MMP2, MMP3, MMP9 and their inhibitors TIMP1 and TIMP2 in human renal cell carcinoma. Oncol Rep. 2006 May;15(5): 1379-84.

27 Chou CJ, Affolter M, Kussmann M. A nutrigenomics view of protein intake: macronutrient, bioactive peptides, and protein turnover. Prog Mol Biol Transl Sci. 2012;108:51-74.

28 Knäuper V, López-Otin C, Smith B, Knight G, Murphy G. Biochemical characterization of human collagenase-3. J Biol Chem. 1996 Jan; 271(3):1544-50. 